J. Product. \& Dev. ,11 (2): 383-391(2006)

\title{
EFFECT OF SOME POLLEN SUBSTITUTES ON BROOD REARING ACTIVITY AND QUEEN PRODUCTION OF HONEYBEE COLONIES
}

\author{
R. E. M. Omar
}

Department of Plant Protection. Fac. Agric. Moshtohor, Benha University, Egypt.

\section{ABSTRACT}

Wheat germ, dried brewer's yeast and defatted soybean flour were offered, in form of cake (paste), as pollen substitutes to honeybee colonies. The effect of such feeding on brood rearing activity and queen production were investigated during 2003/2004 and 2004/2005 seasons in the apiary of Faculty of Agriculture at Moshtohor. Summarized results are as follow:

1- The greatest total sealed brood area was measured during spring season, ranging between 1590.66 (control) - 2471.01 inch $^{2} /$ colony for wheat germ treatment in the first season; 1667.00 and 2538.33 inch $^{2} /$ colony in the second season. The least brood rearing activity, however was detected in winter during 2003/2004 and in autumn during 2004/2005.

2- The cake based on wheat germ induced the highest brood rearing activity in both seasons as the total sealed brood area reached 6874.00 and 7132.67 inch $^{2}$ /colony. Dried brewer's yeast cake came the second class 16210.00 and 5995.67 inch $^{2}$ /colony), followed by soybean cake (5291.00 and 5598.67 inch ${ }^{2}$ (colony). On the other hand, control colonies reared 4475.33 and 4358.35 inch ${ }^{2}$ colony in 2003/2004 and 2004/2005, respectively.

Percent increase in sealed brood area realized due to pollen substitutes feeding attained 52.99, 38.76 and 18.23\% in the first season; 63.67, 37.57 and $28.46 \%$ in the second season for the colonies fed on the cake of wheat germ, dried brewer's yeast and defatted soybean flour, respectively.

Feeding queen rearing colonies on the test pollen substitutes resulted in considerable increase in grafted queen cups acceptance, ranging between 29.49 - $86.44 \%$. In addition, an increase in the emergence of virgin queen, ranging between 45.11-105.10\% was detected in pollen substitute fed colonies. Wheat germ cake proved most potent in enhancing both grafted cups acceptance and virgin queen emergence to be especially during clover season.

Keywords: Pollen substitutes, brood rearing activity, queen production, honeybee colonies.

\section{INTRODUCTION}

Pollen is the primary source of protein, fats, vitamins, and minerals in the diet of the honeybee, Apis mellifera L., and provides all the nutritive elements necessary for life when it is ingested along with nectar and water. However, in any study concerning the nutrition of honey bees, the interaction between larval and adult honeybees is a prime consideration because newly emerged adults must consume pollen during the 1 st 10 days 
after emergence. Without this initial pollen, the brood rearing ability of these bees is drastically impaired, Haydak (1949) since the glands responsible for producing the food fed by nurse bees to the larvae remain underdeveloped and nonfunctional.

Some biological activity of honeybee colonies are induced (enhanced) greatly by protein feeding, especially during the dearth periods when the colonies suffer the shortage of pollen needed to activate the glands responsible for larval foods secretion, Barker (1971).

Therefore, the present work is an attempt to evaluate the efficiency of three pollen substitutes (wheat germ, dried brewer's yeast and defatted soybean flour) in enhancing brood rearing activity and queen production of the fed colonies.

\section{MATERIALS AND METHODS}

The present investigations were carried out in the apiary Faculty of Agriculture, Moshtohor, Benha University during the two successive years 2003/2004 - 2004/2005.

\section{1- Experimental colonies:-}

Twelve honeybee colonies of first hybrid Carniolan bees, Apis mellifera carnica $L$. nearly equal in strength containing at least seven frames covered with bees and headed by open mated hybrid new sister queens. These colonies were divided into four groups, of three colonies each.

\section{2- The diets:-}

The tested diets are:-

1- Soybean flour + bee honey $(2: 1 \mathrm{w} / \mathrm{w})$, the chemical compositions of soybean flour determined by Hammad (2000) is as follows: humidity $6.58 \%$, protein $50.88 \%$, fat $5.41 \%$, fiber $6.54 \%$, ash $6.73 \%$.

2- Wheat germ + bee honey $(2: 1 \mathrm{w} / \mathrm{w})$, the chemical compositions of wheat germ determined by Kent and Amos (1967) is as follows: humidity 9-13\%, protein 22-32\%.

3 - Brewer's yeast + bee honey $(2: 1 \mathrm{w} / \mathrm{w})$, the chemical compositions of dried Brewer's yeast determined by Atallah et al. (1979) is as follows: humidity 9.5\%, crude protein $40.5 \%$, ether extracts $1.5 \%$, ash $6.25 \%$ in addition to vitamin B 1, B2 and nicotinic acid.

Diet mixtures were supplied (sweetened) with powdered sugar to become cakes. The cakes were then offered to the test colonies at the rate of $300 \mathrm{~g}$./colony every 13 days. The cakes were inbagged in perforated plastic saccules and placed over the top bars of brood nest, in addition to sugar syrup $(1: 1 \mathrm{w} / \mathrm{v})$ feeding. Control colonies were offered sugar syrup only.

\section{3- Estimation of brood rearing activity:-}

Areas of sealed worker brood in the test colonies were measured at 12 day intervals during the two successive years using a typical Hoffman frame divided into square inches. This frame was laid against any comb to count the inches of sealed brood.

\section{4- Estimation of queen rearing activity:-}

Doolittle (1880) method used in queen rearing and production that adopted by Laidlow (1979) was followed: A frame with 4 bar containing 60 queen cups(15 queen 
cups/bar) were grafted with worker larvae of 24 hours after hatching. The grafted bars were introduced into queenless colonies until the queen cells were sealed. Percent acceptance of queen cubs after $24 \mathrm{hr}$. of introduction into breeding colony and the number of emerged virgin queens were assessed.

Data obtained were statistically analyzed according to Little and Hills (1975) methods.

\section{RESULTS AND DISCUSSION}

The efficiency of wheat germ, dried brewer's yeast and defatted soybean flour cakes, as pollen substitutes, on brood rearing activity and queen production was studied. Data obtained are presented in Tables (1\&2).

\section{1- Brood rearing activity:}

Sealed brood area in inch $^{2}$ was measured at 12-day intervals allover the successive seasons of 2003/2004 and 2004/2005. Obtained data are summed and tabulated in Table (1) for autumn, winter, spring and summer in both years of study.

Obtained results clear that the total sealed brood area measured during autumn season attained 1197.66, 1192.00, 1051.32 and 911.01 $\mathrm{inch}^{2} /$ colony in 2003/2004; $1072.67,922.68,818.00$ and $634.33 \mathrm{inch}^{2} /$ colony in 2004/2005 for the colonies offered the cakes of wheat germ, dried brewer's yeast and defatted soybean flour and control, respectively. Analysis of data revealed that all test diets induced significantly brood rearing activity as compared to that of the control. However, wheat germ cake proved to be the superior meanwhile soybean flour cake was the inferior.

During winter season, the total sealed brood area reared in the test colonies recorded 1253.67, 1025.00, 904 and $483.33 \mathrm{inch}^{2} /$ colony in 2003/2004; 1314.34, 1071.00, 1029.66 and $453.32 \mathrm{inch}^{2} /$ colony in 2004/2005 season for the colonies fed on wheat germ, dried brewer's yeast and defatted soybean flour cakes and sugar syrup (control), respectively. Analysis of variance clear that wheat germ cake induced the highest brood rearing activity, being insignificantly differed as compared to that of the other two cakes. Generally, the test pollen substitutes were significantly higher than the control in this activity.

The total sealed brood area measured during spring season was the highest among the four seasons of the year, as it reached 2471.01, 2099.01, 1806.34 and 1590.66 and $\mathrm{inch}^{2}$ /colony in 2003/2004; 2538.33, 2130.34, 1912.34 and $1667.00 \mathrm{inch}^{2} /$ colony in 2004/2005 season for the colonies fed on wheat germ, dried brewer's yeast and defatted soybean flour cakes and sugar syrup (control), respectively. Analysis of data indicated that the best diet in inducing brood rearing activity was dried brewer's yeast in the first season and wheat germ in the second one. The differences between means were mostly significant, especially in the second season.

During summer season, the total sealed brood area reared by the test colonies recorded 1924.66, 1894.01, 1529.32 and $1490.33 \mathrm{inch}^{2} /$ colony in the first season; 2207.33, 1871.68, 1838.66 and $1603.67 \mathrm{inch}^{2} /$ colony in the second one for honeybee colonies fed on wheat germ, dried brewer's yeast and defatted soybean flour cakes and sugar syrup (control) colonies, respectively. Statistical analysis revealed that wheat germ 
Table (1): Effect of pollen substitutes feeding on brood rearing activity, brood (inch $2 /$ colony) during 2003/2004 and 2004/2005.

\begin{tabular}{|c|c|c|c|c|c|c|c|c|}
\hline \multirow[b]{3}{*}{ Seasons } & \multirow{3}{*}{ Diets } & \multicolumn{7}{|c|}{ Sealed brood area inch $2 /$ colony } \\
\hline & & \multirow{2}{*}{$\begin{array}{l}\text { Wheat } \\
\text { Germ }\end{array}$} & \multirow{2}{*}{$\begin{array}{c}\text { Dried } \\
\text { Brewer's } \\
\text { yeast }\end{array}$} & \multirow{2}{*}{$\begin{array}{l}\text { Soybean } \\
\text { flour }\end{array}$} & \multirow{2}{*}{ Control } & \multirow{2}{*}{ Total } & \multicolumn{2}{|c|}{ L.S.D. } \\
\hline & & & & & & & 0.05 & $\mathbf{0 . 0 1}$ \\
\hline \multirow{4}{*}{ Autumn } & \multicolumn{6}{|c|}{$2003 / 2004$} & & \\
\hline & Total & 1197.66 & 1192.00 & 1051.32 & 911.01 & 4351.99 & \multirow[b]{2}{*}{28.8} & \multirow[b]{2}{*}{41.4} \\
\hline & Mean & 171.10 & 170.29 & 150.19 & 130.14 & 621.72 & & \\
\hline & $\% *$ & 31.47 & 30.84 & 15.37 & ------ & |----- & \multirow[b]{3}{*}{24.06} & \multirow[b]{3}{*}{32.95} \\
\hline \multirow{3}{*}{ Winter } & Total & 1253.67 & 1025.00 & 904.00 & 483.33 & 3666.00 & & \\
\hline & Mean & 179.10 & 146.43 & 129.14 & 69.05 & 523.72 & & \\
\hline & $\% *$ & 159.38 & 112.07 & 87.04 & ----- & |------ & \multirow[b]{3}{*}{48.17} & \multirow[b]{3}{*}{65.98} \\
\hline \multirow{3}{*}{ Spring } & Total & 2471.01 & 2099.01 & 1806.34 & 1590.66 & 7967.02 & & \\
\hline & Mean & 353.00 & 299.86 & 258.05 & 227.24 & 1138.15 & & \\
\hline & $\% *$ & 55.34 & 31.96 & 13.56 & ----- & ------- & \multirow[b]{3}{*}{32.17} & \multirow[b]{3}{*}{43.6} \\
\hline \multirow{3}{*}{ Summer } & Total & 1924.66 & 1894.01 & 1529.32 & 1490.33 & 6838.32 & & \\
\hline & Mean & 274.95 & 270.57 & 218.48 & 212.90 & 976.90 & & \\
\hline & $\% *$ & 29.14 & 27.09 & 2.62 & & & & \multirow{3}{*}{$\begin{array}{c}--- \\
--\end{array}$} \\
\hline \multirow{3}{*}{$\begin{array}{l}\text { Grand } \\
\text { season }\end{array}$} & Total & 6847.00 & 6210.00 & 5291.00 & 4475.33 & 22823.33 & & \\
\hline & Mean & 244.53 & 221.78 & 188.96 & 159.83 & ------- & & \\
\hline & $\% *$ & 52.99 & 38.76 & 18.23 & ----- & ----- & ----- & ---- \\
\hline \multicolumn{9}{|c|}{$2004 / 2005$} \\
\hline \multirow{3}{*}{ Autumn } & Total & 1072.67 & 922.68 & 818.00 & 634.33 & 3447.68 & & \\
\hline & Mean & 153.24 & 131.81 & 116.86 & 90.62 & 492.53 & 26.47 & 36.4 \\
\hline & $\% *$ & 69.01 & 45.46 & 28.95 & ------ & ------ & & \\
\hline & Total & 1314.34 & 1071.00 & 1029.66 & 453.32 & 3868.32 & & \\
\hline Winter & Mean & 187.76 & 153.00 & 147.10 & 64.76 & 552.62 & 62.4 & 85.5 \\
\hline & $\% *$ & 189.94 & 136.26 & 127.14 & ------ & ------- & & \\
\hline & Total & 2538.33 & 2130.34 & 1912.34 & 1667.00 & 8248.01 & & \\
\hline Spring & Mean & 362.62 & 304.33 & 273.19 & 238.14 & 1178.28 & 51.43 & 70.45 \\
\hline & $\% *$ & 52.27 & 27.79 & 14.72 & ------- & ------- & & \\
\hline & Total & 2207.33 & 1871.68 & 1838.66 & 1603.67 & 7521.34 & & \\
\hline Summer & Mean & 275.92 & 233.96 & 229.83 & 200.46 & 940.17 & 32.17 & 43.6 \\
\hline & $\% *$ & 37.64 & 16.71 & 14.65 & -------- & -------- & & ---- \\
\hline & Total & 7132.67 & 5995.67 & 5598.67 & 4358.33 & 23085.35 & & -- \\
\hline & Mean & 254.73 & 214.13 & 199.96 & 155.65 & ------ & ------ & ---- \\
\hline & $\% *$ & 63.66 & 37.57 & 28.46 & ------- & ------- & - & --- \\
\hline
\end{tabular}

$\% *=\%$ Increased

and dried brewer's yeast in the first season and wheat germ in the second season induced the highest significant brood rearing activity, while soybean flour cake and sugar syrup fed colonies (control) reared the least significant brood area. Data obtained are in partial accordance with those of Free and Williams (1976), Herbert and Shimanuki (1982), Abu-zaid and Abd-Alfattah (1989), Baidya et al. (1993), and EI-Shaarawi (2001). 
2- Queen rearing activity:

a) Percent acceptance of grafted queen cups:

Data presented in Table (2) clear that feeding queen rearing colonies on the cakes of wheat germ, dried brewer's yeast and soybean flour during citrus season increased the rate of grafted queen cups acceptance by 45.51, 32.05 and $33.97 \%$ in 2003/2004 season; 42.95, 29.49 and $35.56 \%$ in $2004 / 2005$ season, respectively. The corresponding figures during clover season were $86.44,56.78$ and $64.41 \%$ in the first season; 85.22, 75.62 and $66.96 \%$ in the second season. The rates of queen cups acceptance during cotton season were intermediate, as they recorded $64.89,45.04$ and $47.33 \%$ in 2003/2004 season; $76.61,48.39$ and $55.65 \%$ in 2004/2005 season, respectively.

\section{b) Percent emergence of virgin queens:}

Obtained results clear that the rate of increase in the queen emergence was the highest in the colonies fed on wheat germ cake. For instance, the rate of increase in \% emergence attained $63.78,52.76$ and $55.91 \%$ in 2003/2004; 57.14, 45.11 and $50.38 \%$ in $2004 / 2005$ during citrus season, the rate of increase during clover season were 89.58 , 81.25 and $83.33 \%$ in 2003/2004; $105.10,61.62$ and $88.89 \%$ in 2004/2005 season, and were during cotton season; $91.84,74.49$ and $73.47 \%$ in the first season; $98.10,65.71$ and $61.90 \%$ in the second season for the colonies fed on the cakes wheat germ, dried brewer's yeast and soybean flour over the percentage of queen emergence recorded for control colonies, respectively.

Queen cups acceptance and queen production depend upon many factors i.e climatic factors, especially ambient air temperature, relative humidity and daytime length. The most favorable climatic conditions are prevailing during May (clover season). This factors studying by Atmowidjojo et al.(1997), Osborne and Oldroyd (1999) and Woyke et al.(2004). Followed by July and August (cotton season) meanwhile the climatic factors suffer (manifest) great change during March and April (citrus season) David et al.(2000). In addition, food availability and quality has its great role, as the abundance of pollen or pollen substitute enhances the development of larval food glands and enable them to secrete sufficient royal jelly needed for raising queen larvae of well built bodies. Svoboda et al. (1986).

Other factors of low or great importance such as the existence of natural enemies (wasps, frogs, mite, reptiles and birds like bee eater; (Meropes spp.) and diseases infection may have a decisive role in this respect. Similar results were also reported by Revell (1960), Zaytoon et al. (1988), El-Shemy (1997), Shimanuki et al.(1992), and Malone et al.(2001),

A well known fact that most honeybee diseases, which play adverse role on colony activities, are epidemically spread during cold season autumn and winter). On the other hand, wasps and bee eater Meropes spp. are abundantly occurred during summerseason. These phenomena in addition to tropic and weather factors could provide logic explanation to the low rate of queen rearing activity of honeybee colonies during citrus and cotton seasons, and the higher activity during clover season (May). 


\section{REFERENCES}

Abu-zaid, M. I. and M. A. Abd-Alfattah (1989): New pollen - supplements for feeding honeybees and their effect on brood rearing and honey production. Bull. Soc. Ent. Egypte, 68: 207-214.

Atmowidjojo, A. H., D. E. Wheeler, E. H. Erickson, and A. C. Cohen (1997): Temperature Tolerance and Water Balance in Feral and Domestic Honey Bees, Apis mellifera L.. Camp. Aiochem. Physiol., 118A (4): 1399-1403.

Atallah, M. A.; I. B. Sheta and A. A. Abd-Elnaby (1979): Nutritive value of some pollen substitutes for the honeybees. Bull. Soc. Ent. Egypt., 26: 185-190.

Baidya, D. K.; M. Sasaki and M. Matsuka (1993): Effect of pollen substitute feeding site on brood rearing in honeybee colonies. Appl. Entomol. Zool., 28(4): 590-592.

Barker, R. J. (1971): The influence of brood inside the hive on pollen collection by honeybee colonies. J. Apic. Res.,10(1): 23-26.

David, R. T., H. Shanti and J. C. F. David (2000): The influence of queen age and quality during queen replacement in honeybee colonies. Animal Behav., 59 (1): 97 101.

Doolittle, G. M. (1980): Introducing queens. Glean. Bee cult., 8(4): 158 - 159. (C.f. Laidlaw. 1979).

EI-Shaarawi, M. 0. (2001): The effect of feeding honeybee colonies by pollen substitutes on worker brood rearing and citrus honey. J. Agric. Sci. Mansoura Univ., 26(6): 3983-3987.

El-Shemy, A. A. M. (1997): Effect of two pollen substitutes on brood rearing and some activities of honeybee colonies. Bull. Ent. Soc. Egypt, 75: 1-11.

Free, J. B. and I. H. Williams (1976): The effect on the foraging behaviour of honeybees of the relative locations of the hive entrance and brood combs. Applied Animal Ethnology, 2 (2): 141-154.

Hammad, A. A. (2000): Chemical and technological studies on soybean proteins. Ph. D. Thesis, Fac. Agric., Moshtohor, Zagazig Univ.

Haydak, M.H. (1949): Causes of deficiency of soybean flour as a pollen substitute for honeybees. J. Econ. Entomol., 42(4): 573-579.

Herbert, E.W. and H. Shimanuki, (1982): Effect of population density and available diet on the rate of brood rearing by honeybee offered a pollen substitute. Apidologie., 13 (1 ):21-28.

Svoboda, J. A., E. W. Herbert, and M. J. Thompson (1986): Sterols of organs involved in brood food production and of royal jelly in honey bees. J. Insect Bioch., 479-482

Osborne, K. E. and B. P. Oldroyd (1999): Possible causes of reproductive dominance during emergency queen rearing by honeybees. Animal Behav., 58 , 267-272.

Kent, J. and Amos (1967): Chemical Composition of Wheat Germ. U. S. Feed Grains Council (1994).

Laidlaw, H.H. (1979):Contemporary Queen Rearing. Hamilton, Ii, USA; Dadant and Sons. 199 pp. 
Little, T. M. and F. J. Hills (1975): Statistical Methods in Agricultural Research. Book store University of California, Davis 95616. pp 242.

Malone, L. A., H. S. Gatehouse and E. L. Tregidga (2001): Effects of Time, Temperature, and Honey on Nosema apis (Microsporidia: Nosematidae), a Parasite of the Honeybee,Apis mellifera (Hymenoptera: Apidae). J. of Inverteb. Path. 77, $258-268$.

Revell, I. L. (1960): Longevity of refrigerated nosema spores-Nosema apis, a parasite of honey bees. J. Econ. Entomol., 53, 1132-1133.

Shimanuki, H.; D. A. Knox; B. Furgala; D. M. Caron and J. L. Williams (1992): Diseases and pests of honey bees. In "The Hive and the Honey Bee" (J. M. Graham, Ed.), pp. 1083-1151.

Woyke, J.; J. Wilde, and C.C. Reddy (2004): Open-air-nesting honey bees Apis dorsata and Apis laboriosa deferent from the cavity-nesting Apis mellifera and Apis cerana in brood hygiene behaviour. J. of Inver. Path., 86: 1- 6.

Zaytoon A. A.; M. Matsuka and M. Sasaki (1988): Feeding efficiency of pollen substitutes in a honeybee colony: effect of feeding site on royal jelly and queen production. Appi. Ent. Zool., 23(4): 481- 487. 


\section{تأثير بعض بدائل حبوب اللقاح على نشاط تربية الحضنة وإنتاج الملكات في طوائف نحل العسل}

\section{رضا السبا محمد عمر قسم وقاية النبات-كلية الزراعة بمشتهر - جامعة بنها - بنها - ج.م.ع.}

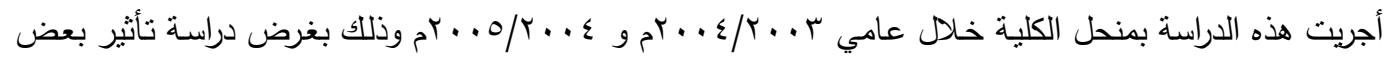
بدائل حبوب اللقاح مثل (جنين القمح - الخميرة الجافة - دقيق فول الصويا منزوع الدسم) والمستخدمة في تغذية طوائف نحل بله العسل صناعيا كبدائل لحبوب اللقاح الطبيعية على نشاط طوائف نحل العسل في نربية الحضنة وإنتاج الملكات.

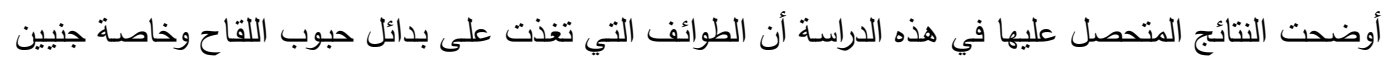

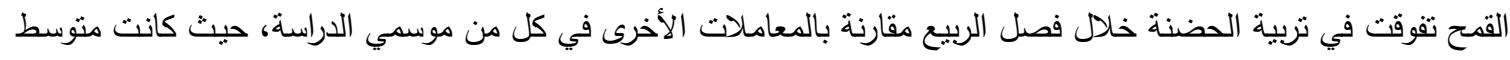

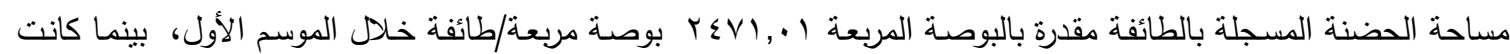

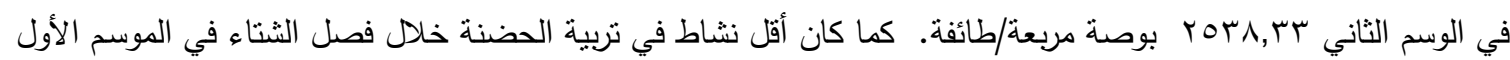

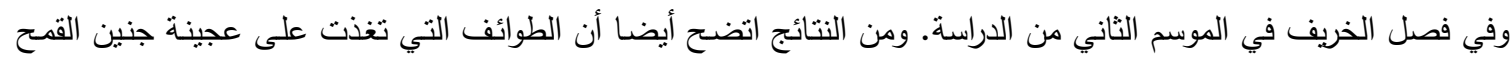

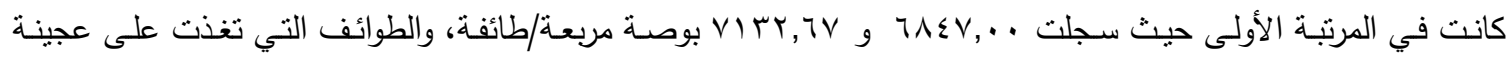

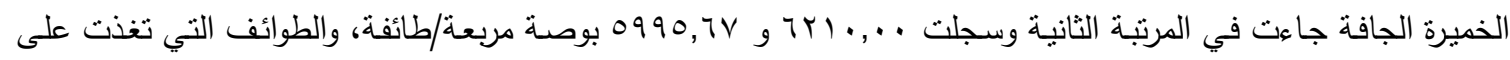

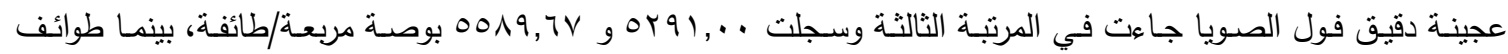

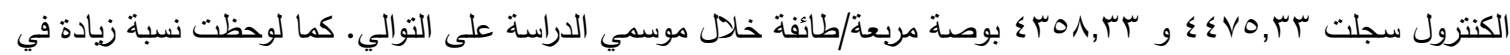

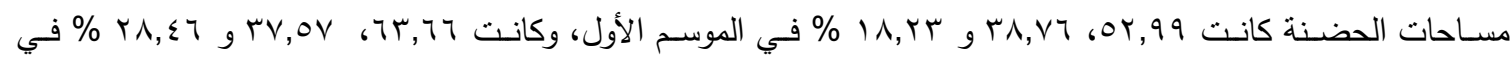
الموسم الثاني في الطوائف التي تغذت على عجينة جنين القـح، عجينة الخميرة الجافة، عجينة دقيق فول الصويا مقارنة بطوائف الكنترول على النوالي. كما اتضح من النتائج أيضا أن طوائف نحل العسل التي تغذت على بدائل حبوب اللقاح قد أظهرت تفوقا ملحوظا

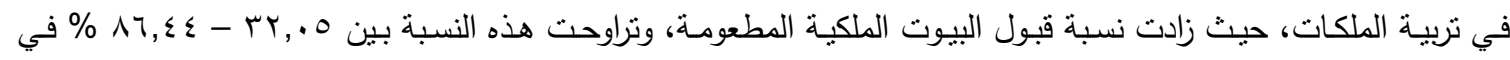

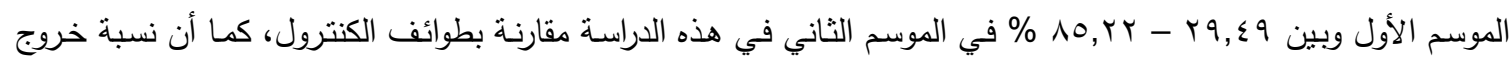

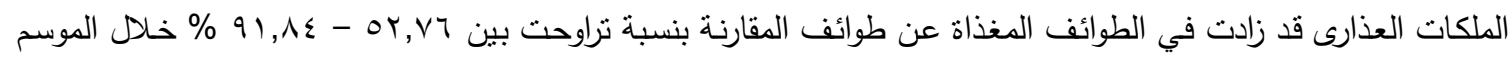

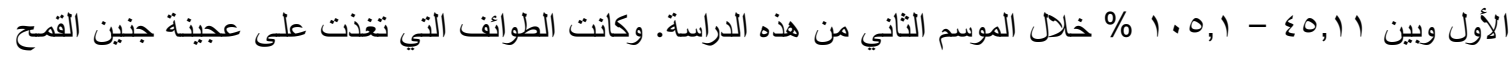

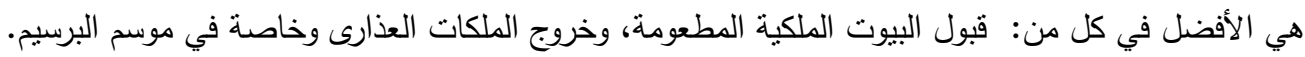

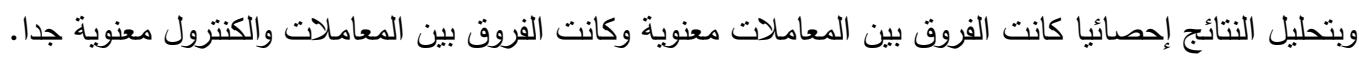

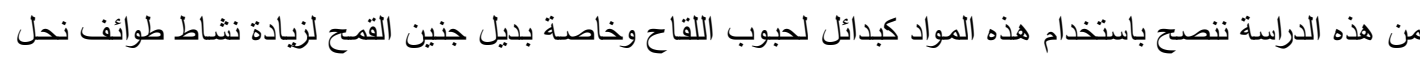

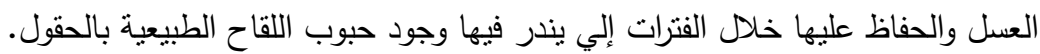


